\title{
INTRACEREBRAL HEMORRHAGE DUE TO INTRAVENOUS THROMBOLYTIC TREATMENT IN ACUTE ISCHEMIC STROKE
}

\author{
Tuğçe MENGI, Yaprak SECIL, Aysel COBAN, Mehmet CELEBISOY, Yeşim BECKMANN, \\ Tülay KURT INCESU, Behiye GONENC OZER
}

\author{
Katip Çelebi University Ataürk Training and Research Hospital, Neurology Clinic, İzmir, TURKEY
}

\begin{abstract}
OBJECTIVE: Acute ischemic stroke is an emergency which can be treated by intravenous thrombolytic treatment in the first 4.5 hours. The most important complication effecting prognosis of intravenous thrombolysis is the symptomatic intracerebral hemorrhage. The aim of our study is to determine the risk factors of intracerebral hemorrhage due to intravenous thrombolytic treatment.

METHODS: In our study, 12 patients with intracerebral hemorrhage due to intravenous thrombolytic therapy hospitalized in Neurological Intensive Care Unit between 2009-2014 were revised retrospectively.

RESULTS: Twelve patients who had intracerebral hemorrhage due to thrombolytic treatment were included. Nine of the cases $(75.0 \%)$ had asymptomatic intracerebral hemorrhage, whilst 3 (\% 25.0) had symptomatic intracerebral hemorrhage.

CONCLUSION: There were many studies aiming to put forth the risk of intracerebral hemorrhage associated with intravenous thrombolytic therapy. Advanced age, body weight $>95 \mathrm{~kg}$, the history of diabetes mellitus and hypertension, the use of antiaggregant agents, symptom-treatment interval, hyperglycemia at the time of arrival, high value of the National Institutes of Health Stroke Scale, the presence of dense artery in first cranial computerized tomography, the size of the ischemic infarct were determined as risk factors. Also, our results showed that hyperglycemia and high blood pressure was associated with parenchymal hemorrhage.
\end{abstract}

Keywords: Ischemic stroke, neurological intensive care, parenchymal hemorrhage, symptomatic intracerebral hemorrhage, thrombolytic therapy.

\section{AKUT İSKEMIK İNMEDE İNTRAVENÖZ TROMBOLITTIK TEDAVIYE BAĞLI İNTRASEREBRAL HEMORAJİ}

\section{ÖZET}

AMAÇ: Akut iskemik inme intravenöz trombolitik tedavi ile ilk 4,5 saatte tedavi edilebilen acil bir durumdur. İntravenöz trombolitik tedavide prognozu en çok etkileyen komplikasyon semptomatik intraserebral hemorajidir. Çalışmamızın amacı intravenöz trombolitik tedaviye bağlı intraserebral hemorajinin risk faktörlerini belirlemektir.

GEREÇ ve YÖNTEM: Çalışmamızda 2009-2014 arasında Nöroloji Yoğun Bakım Ünitesinde intravenöz trombolitik tedaviye bağlı intraserebral hemoraji saptanan 12 hasta retrospektif olarak değerlendirildi.

BULGULAR: İntravenöz trombolitik tedaviye bağlı intraserebral hemorajinin saptandığı 12 hasta dahil edildi. Olguların 9'unda $(\% 75,0)$ asemptomatik intraserebral hemoraji mevcutken, 3'ünde $(\% 25,0)$ semptomatik intraserebral hemoraji gözlendi.

SONUÇ: İntravenöz trombolitik tedavi ile ilişkili intraserebral hemoraji riskini ortaya koymak amacıyla birçok çalışma yapılmıştır. İleri yaş, vücut ağırlığı ( $>95 \mathrm{~kg}$ ), hipertansiyon ve diyabetes mellitus öyküsü, antiaggregan kullanımı, semptom-tedavi zamanı, başvuru anında hiperglisemi varlığı, NIHSS değerinin yüksekliği, ilk kraniyal bilgisayarlı tomografide dens arter bulgusunun varlığı ve iskemik infarktın büyüklüğü risk faktörleri olarak belirlenmiştir. Bizim çalışmamızda ise hiperglisemi ve yüksek kan basıncı parankimal hemoraji ile ilişkili bulunmuştur.

Anahtar Sözcükler: İskemik inme, nöroloji yoğun bakım, parankimal hemoraji, semptomatik intraserebral hemoraji, trombolitik tedavi.

Corresponding author: Tugce Mengi, MD. Katip Çelebi University Ataürk Training and Research Hospital, Neurology Clinic, İzmir, Turkey.

Telephone: +902322434343 E-mail: tugceangin@gmail.com

Received: $29.09 .2016 \quad$ Accepted: 14.11 .2016

This article should be cited as following: Mengi T, Secil Y, Coban Ay, Celebisoy M, Beckmann Y, Kurt İncesu T, Gönenç Özer B. Intracerebral haemorrhage due to intravenous thrombolytic treatment in acute ischemic stroke. Turkish Journal of Cerebrovascular Diseases 2017; 23 (1): 17-20. doi:10.5505/tbdhd.2017.39200 


\section{INTRODUCTION}

Acute ischemic stroke is an emergency which can be treated by recombinant tissue plasminogen activator (rt-PA) and intravenous (IV) thrombolytic treatment in the first 4.5 hours $(1,2)$. The most important complication effecting prognosis of IV thrombolysis is the symptomatic intracerebral hemorrhage (SICH) $(3,4)$.

Symptomatic intracerebral hemorrhage was defined as type 2 parenchymal hemorrhage (PH) causing a rise of 4 or more in the National Institutes of Health Stroke Scale (NIHSS) or death in the safe implementation of thrombolysis in Safe Implementation of Thrombolysis in Stroke Monitoring Study (SITS-MOST) (1).

Different studies showed many risk factors for intracerebral hemorrhage (ICH) associated with thrombolytic treatment such as clinical features of the patient, radiologic features of the infarct, the time and type of treatment given. It is important to choose the right patient for thrombolytic treatment in order to reduce the risk of ICH. The aim of this study is to determine the risk factors of ICH due to rt-PA treatment.

\section{MATERIAL AND METHODS}

The data of 12 patients hospitalized in our Neurological Intensive Care Unit with ICH due to IV thrombolytic treatment between 01.06.2009 and 15.09.2014 were revised retrospectively.

Patients applied the first 3 or 4.5 hours after the beginning of the symptoms and diagnosed as ischemic stroke were assessed for IV rt-PA. For suitable patients (no contraindications for rt-PA and known exact time of the symptoms) rt-PA was applied with a dose of $0,9 \mathrm{mg} / \mathrm{kg}$. NIHSS was remeasured 24 hours after the end of the treatment and the presence of ICH was investigated with cranial computerized tomography (CT).

The age, sex, the time interval between the beginning of the symptoms and the hospital arrival time (symptom-to-door time), the time interval between the beginning of the symptoms and the IV rt-PA treatment (symptom-to-needle time), the presence of heart failure (HF), atrial fibrillation (AF), the use of antiaggregant agents or anticoagulants, the levels of blood glucose and blood pressure before the rt-PA treatment were noted in cases with ICH after the thrombolytic treatment.
The presence of ICH was defined by European Cooperative Acute Stroke Study (ECASS) I and II radiologically (Table 1$)(4,5)$. The symptomatic feature of the hemorrhage was determined according to the criteria of SITS MOST (1).

Table 1. The definition of intracerebral hemorrhage by ECASS I and II $(4,5)$.

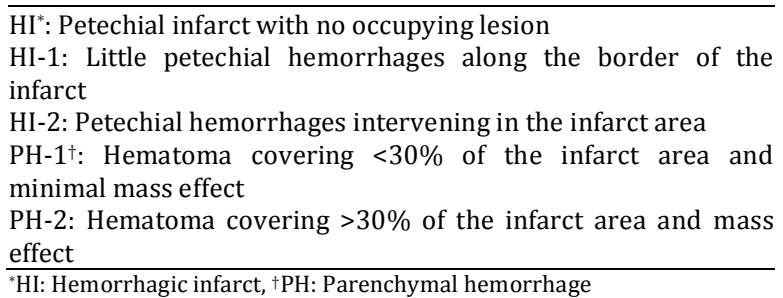

\section{RESULTS}

Among 12 patients with mean age of $62.5 \pm$ 8.74 and age range between 55 and 79,8 were male $(66.7 \%)$ and 4 were female $(33.3 \%)$.

The symptom-to-door time, the symptom-toneedle time, the presence of $\mathrm{HF}, \mathrm{AF}$, the use of antiaggregant agents, the levels of blood glucose and blood pressure before the rt-PA treatment, the presence of dense middle cerebral artery and early ischemic findings were presented in Table 2 .

Table 2. The clinical features of the patients.

\begin{tabular}{lc}
\hline & Patients $(\mathrm{n}=12)$ \\
Atrial fibrillation, $\mathrm{n}(\%)$ & $5(41.7)$ \\
Heart failure, n (\%) & $6(50.0)$ \\
Use of antiaggregant agents, n (\%) & $8(66.7)$ \\
Symptom-to-door time, mn, mean \pm SD & $77.9 \pm 26.2$ \\
Symptom-to-needle time, mn, mean \pm SD & $153.3 \pm 49.7$ \\
Hyperglycemia $(>180 \mathrm{mg} / \mathrm{dl}), \mathrm{n}(\%)$ & $3(25.0)$ \\
High blood pressure $(\geq 180 / 100), \mathrm{n}(\%)$ & $4(33.3)$ \\
\hline
\end{tabular}

Before thrombolytic treatment 4 patients (33.3\%) had a blood pressure over 185/110 mmHg. Standard doses of esmolol or sodium nitroprussiade was applied to these cases and the blood pressure was taken under control before rtPA treatment. PH was detected in all 4 cases with pre-treatment blood pressure $>185 / 110 \mathrm{mmHg}$ by cranial CT.

The mean of glucose levels was $139.5 \pm 44.0$ $\mathrm{mg} / \mathrm{dl}$ before thrombolytic treatment. $\mathrm{PH}$ was detected in all 3 cases with glucose levels $>180$ $\mathrm{mg} / \mathrm{dl}$ by cranial CT.

The presence of ICH was assessed by cranial CT 24 hours after the treatment. Two of all 
intracerebral hemorrhages (16.7\%) were hemorrhagic infarct (HI) type-1, 2 (16.7\%) were HI type-2, 3 (25.0\%) were $\mathrm{PH}$ type-1, 5 were (41.7\%) PH type-2 (Table 3), (Figure I). The symptomatic features of the hemorrhage were defined according to the criteria of SITS MOST. Nine patients $(75.0 \%)$ showed asymptomatic intracerebral hemorrhage (AICH), whilst 3 (25.0\%) had SICH.

Five of the cases with ICH were exitus (41.7\%). All exitus cases had AF and/or HF. All of SICH patients were exitus during hospitalization interval.

Table 3. Intracerebral hemorrhage types.

\begin{tabular}{llc}
\hline & $\mathrm{N}$ & $\%$ \\
\hline${ }^{*}$ HI type-1 & 2 & 16.7 \\
HI type-2 & 2 & 16.7 \\
†PH type-1 & 3 & 25.0 \\
PH type-2 & 5 & 41.7
\end{tabular}

${ }^{*} \mathrm{HI}$ : Hemorrhagic infarct, ${ }^{\mathrm{PH}} \mathrm{H}$ : Parenchymal hemorrhage
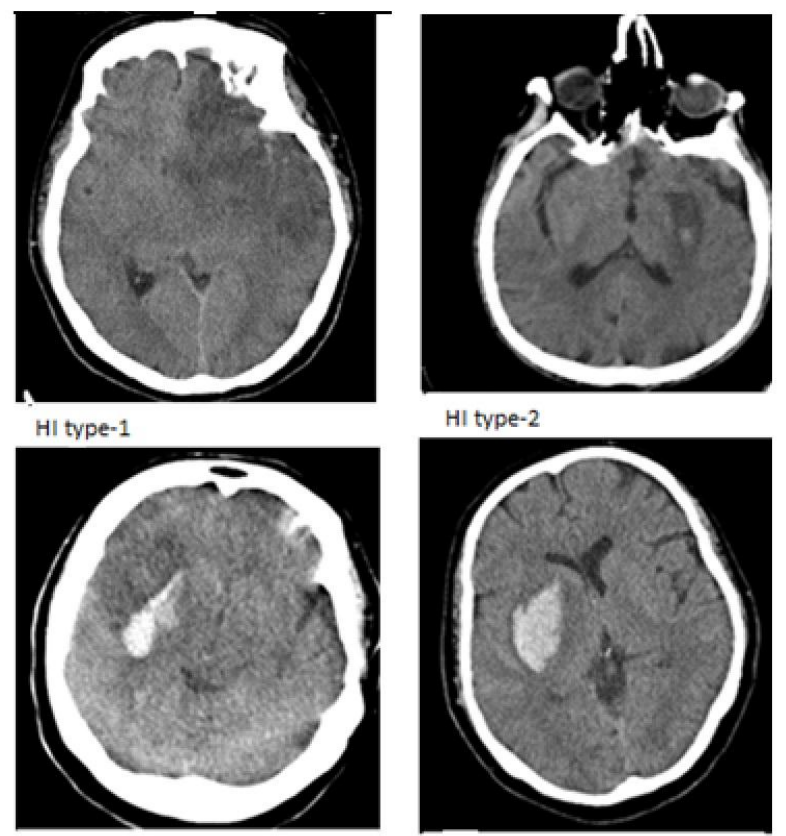

PH type-1

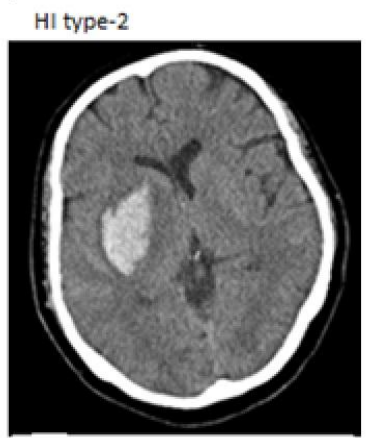

PH type-2

Figure I. Intracerebral hemorrhage types.

\section{DISCUSSION}

There were many studies aiming to put forth the risk of ICH associated with IV thrombolytic therapy. Advanced age, body weight $>95 \mathrm{~kg}$, the history of diabetes mellitus and hypertension, the use of antiaggregant agents, symptom-treatment interval, hyperglycemia at the time of arrival, high value of NIHSS, the presence of dense artery in first cranial CT, the size of the ischemic infarct were determined as risk factors by the several studies $(1,3,6,7)$.

In the study of Mazya et al, high blood pressure was detected as an independent risk factor for SICH, in addition to the results of ECASS II showing the relationship between basal systolic blood pressure and $\mathrm{PH}(1,6)$. In our study, PH was detected in all cases who had blood pressure $\geq 185 / 110 \mathrm{mmHg}$ before the thrombolytic therapy. In the study of PROACT II glucose level $>200$ $\mathrm{mg} / \mathrm{dl}$ at the time of the arrival was found to be related to SICH however, Mazya et al stated that basal glucose level $>10 \mathrm{mmol} / \mathrm{L}$ was an independent risk factor for SICH $(1,5,8)$. All of our cases with basal glucose level $>180 \mathrm{mg} / \mathrm{dl}$ had $\mathrm{PH}$ after thrombolytic therapy.

In ECASS II study, PH and SICH was more common in patients with congestive HF (6). HF and/or AF was detected in all of our cases with SICH. This situation preoccupied that hemorrhagic complications were more common in cardioembolic strokes. In ECASS II study cardiac embolism was found to be associated with aggressive hemorrhagies (6). It is known for many years that in medium and large sized infarcts due to cardioembolic reasons, hemorrhagic transformation could develop (9). A local vascular spasm due to obliteration of a large artery with a thrombus and dissolving of this spasm and the fragmentation leading the thrombus to distal parts of the artery forming a capillary reperfusion and endothelial injury is accepted as the main mechanism for hemorrhagic transformation seen in cardioembolic infarcts (10). Recanalization of occluded vessels are seen more common in embolic strokes than in non-embolic strokes. In addition, the size of the infarct area is one of the main reasons of hemorrhage in cardioembolic strokes (11). In our study, when all patients with ICH were evaluated, 5 of 12 patients $(41.7 \%)$ had AF, whilst 6 (50.0\%) had HF.

Intravenous thrombolytic therapy is the only efficacy proved treatment in acute stroke patients applied in the first 4.5 hour and the most important prognostic complications are SICH and $\mathrm{PH}$. In our study, all of SICH patients were exitus during hospitalization interval. 


\section{REFERENCES}

1. Mazya M, Egido JA, Ford GA, et al.; SITS Investigators. Predicting the risk of symptomatic intracerebral hemorrhage in ischemic stroke treated with intravenous alteplase: Safe implementation of treatments in stroke (SITS) symptomatic intracerebral hemorrhage risk score. Stroke. 2012;43(6):1524-31.

2. Hacke W, Kaste M, Bluhmki E, et al.; ECASS Investigators. Thrombolysis with alteplase 3 to 4.5 hours after acute ischemic stroke. N Engl J Med. 2008;359(3):1317-29.

3. Mazya MV, Bovi P, Castillo J, et al. External validation of the SEDAN score for prediction of intracerebral hemorrhage in stroke thrombolysis. Stroke. 2013;44(6):1595-600.

4. Trouillas P, Von Kummer R. Classification and pathogenesis of cerebral hemorrhages after thrombolysis in ischemic stroke. Stroke. 2006;37(2):556-61.

5. Khatri P, Wechsler LR, Broderick JP. Intracranial hemorrhage associated with revascularization therapies. Stroke. 2007;38(2):431-40.
6. Larrue V, von Kummer R, Müller A, et al. Risk Factors for severe hemorrhagic transformation in ischemic stroke patients treated with recombinant tissue plasminogen activator: a secondary analysis of the EuropeanAustralasian Acute Stroke Study (ECASS II). Stroke. 2001;32(2):438-41.

7. Lou M, Safdar A, Mehdiratta M, et al. The HAT Score A simple grading scale for predicting hemorrhage after thrombolysis. Neurology. 2008;71(18):1417-23.

8. Kase CS, Furlan AJ, Wechsler LR, et al. Cerebral hemorrhage after intra-arterial thrombolysis for ischemic stroke: the PROACT II trial. Neurology. 2001;57(9):1603-10.

9. Hornig $\mathrm{CR}$, Bauer $\mathrm{T}$, Simon $\mathrm{C}$, et al. Hemorrhagic transformation in cardioembolic cerebral infarction. Stroke. 1993;24(3):465-8.

10. Arboix A, Alió J. Cardioembolic stroke: clinical features, specific cardiac disorders and prognosis. Curr Cardiol Rev. 2010;6(3):150-61.

11. Okuda Y, Yamaguchi T, Minematsu K, et al. Hemorrhagic transformation in cerebral embolism. Stroke. 1989;20(5):598-603. 